Article

\title{
Environmental, Social, and Governance Incidents and Bank Loan Contracts
}

\author{
Ruoyu He ${ }^{1}$, Xueli Chen ${ }^{2}$, Cheng Chen ${ }^{3}$, Jianqiao Zhai ${ }^{3}$ and Lixin Cui ${ }^{3, *}$ \\ 1 Renmin Business School, Renmin University of China, Beijing 100872, China; heruoyu@ruc.edu.cn \\ 2 Institute of Journalism and Communication, Chinese Academy of Social Sciences, Beijing 100021, China; \\ chenx1@cass.org.cn \\ 3 School of Management and Economics, Beijing Institute of Technology, Beijing 100081, China; \\ 1120202251@bit.edu.cn (C.C.); $1120200036 @$ bit.edu.cn (J.Z.) \\ * Correspondence: cuilixin@bit.edu.cn
}

Citation: He, R.; Chen, X.; Chen, C.; Zhai, J.; Cui, L. Environmental, Social, and Governance Incidents and Bank Loan Contracts. Sustainability 2021,

13, 1885. https://doi.org/10.3390/ su13041885

Academic Editor: Giuliana Birindelli Received: 31 December 2020

Accepted: 26 January 2021

Published: 9 February 2021

Publisher's Note: MDPI stays neutral with regard to jurisdictional claims in published maps and institutional affiliations.

Copyright: (c) 2021 by the authors. Licensee MDPI, Basel, Switzerland. This article is an open access article distributed under the terms and conditions of the Creative Commons Attribution (CC BY) license (https:// creativecommons.org/licenses/by/ $4.0 /)$.

\begin{abstract}
We investigated how a borrower's adverse environmental, social, and governance incidents affect bank loan contracts. Using a sample of 2001 publicly traded US firms during the period from 2007 to 2016, we found that loans initiated after the occurrence of a firm's environmental, social, or governance-related incident have a significantly higher spread and a lower loan size. Our sample contained firms covered by RepRisk, as RepRisk began tracking firms' environmental, social, and governance-related incidents in January 2007. Further analysis showed that the influence on loan contracts is more pronounced in younger firms, which verifies that environmental, social, and governance-related incidents have significant influence and higher information asymmetry. In addition, a test of the timing of the environmental, social, and governance-related incidents in a year further strengthened our conclusions. Moreover, the impact of environmental, social, and governance-related incidents on loan contracts was also reflected in other non-monetary items, such as the duration of a loan contract, requests for collateral, and the frequency of covenants, as well as the lender structure. This paper adds to the discussion on the economic effects of environmental, social, and governance-related incidents on bank contracts. More broadly, our results contribute to the public policy discussion on the role banks should play in the transition to a low-carbon and sustainable economy.
\end{abstract}

Keywords: environmental, social, and governance incidents; bank loan; loan cost; loan size

\section{Introduction}

Sustainable finance related to environmental, social, and governance issues has attracted growing attention in recent decades, not only for stakeholders, but also for global politics [1] and, evidently, for researchers. The role of environmental, social, and governance (hereafter, ESG) information has recently been discussed in the literature.

For example, Escrig-Olmedo et al. [2] demonstrated the huge value relativity of ESG exposure. In addition, there are more and more studies starting to investigate the economic consequences of ESG incidents in terms of performance, market reaction, and stakeholders' behavior. Tarmuji et al. [3] studied the economic consequences of ESG incidents in Malaysia and Singapore. Using the data from the ASSET 4 database, they found that social and governance practices significantly impact economic performance. Sahut and PasquiniDescomps [4] documented a positive market reaction to good ESG performance in the UK stock market; however, there has been no significant market reaction to ESG performance in the Swiss and US stock markets. In addition, some studies have focused on or isolated the individual dimensions of ESG performance. For example, Bauer and Hann [5] indicated that penalties and liabilities arising from environmental and climate negligence affect the credit standing of companies. Barnett et al. [6] estimated the social cost of carbon emission by combining the asset pricing method and decision theory. They showed that the rise in 
sea levels and climate risk can be reflected in house prices. Above all, the impact of a firm's environmental, social, and governance activities is absent from a bank loan perspective.

Given the growing attention being paid to sustainable financing and the growing severity of environmental issues, governments and corporations are being urged to undertake investment actions to enhance their ESG performance [7]. In particular, banks are becoming one of the key points for improving ESG performance, as tracking such activities requires a large amount of investment, which needs financing. In addition, some studies have investigated whether a single dimension of ESG performance influences public firms' financing activities. Ginglinger and Moreau [8] found that a higher climate risk lowers the leverage ratio, which means that it is much harder for these firms to obtain a loan contract. Allman [9] found that a higher environmental risk decreases the possibility of obtaining a loan, resulting in a low debt ratio. In addition to these, some studies have tackled this issue by using composite ESG measures. For example, firms will have higher loan costs and lower credit ratings if they face more social and environmental concerns [5].

Recently, regulations and standards have been implemented that encourage banks to incorporate the possibility of increased credit risk. Particularly, low-carbon economic development requires companies to meet their sustainability and adaptation requirements related to environmental protection [10]. As a result, lending decisions consider environmental and social concerns due to the growing pressure from investors and regulators. The costs and risks related to transition and compliance can impact the future cash flows of companies and can increase the credit risk for their lenders. There are also increasing pressures on banks to divest carbon-intensive and polluting industries. This might push banks to consider companies' ESG performances.

For public firms, among the vital components are financing activities, which are a straightforward way to raise capital. Naturally, financial institutions such as banks consider the economic situation of a firm when issuing a loan contract (e.g., [11]). Furthermore, there is evidence that banks consider corporate social responsibility (CSR) with regard to their responsibilities as "corporate citizens" and safeguarding their reputation (e.g., [12]). Additionally, firms pay attention to their CSR. For example, Barnea and Rubin [13] indicated that firms may overinvest in CSR to satisfy the prediction of managers to improve their reputation, where the shareholders pay the expense. Ge and Liu [14] proved that better CSR performance leads to better credit ratings. Companies with better CSR performance can issue bonds with lower costs and are thus more visible as high-quality bond issuers. In previous research on CSR and loan costs, companies have argued that worse CSR implies a higher default risk, as they do not have enough funding to support their CSR activities [12]. Unlike CSR, which covers many dimensions of firms' social responsibility activities, ESG performance is a more direct measure of firms' environmental, social, and governancerelated activities, which are directly related to environmental and sustainable development. In addition, firms' performances with regard to environmental, social, and governance issues can be more easily observed by external stakeholders.

We argue that an ESG incident could impact loan costs through at least two aspects. First, previous studies have found that firms' social responsibility behavior could reflect their financial situation and could be viewed as a predictor of future cash flows [12]. Therefore, the investment in ESG should be related to the credit risk and future default risk, i.e., firms that invest less in ESG may face a difficult financial situation and subsequently suffer from higher default risk. The second is reputational risk. Reputational risks stem from the possibility of being associated with a client firm's environmental or social scandal. A premium is required in order to judge the lending relationship with a firm that the public and the bank's other stakeholders may view as having questionable social or environmental behavior [15]. Based on these two arguments, we conjecture that a firm's ESG incidents could increase loan costs. Similar to existing studies, we treated the ESG of client firms as a type of soft information that banks could consider when making a loan contract decision, that is, they could provide less favorable loan contract terms for borrowers that have ESG incidents. Therefore, we predicted that firms with ESG incidents may have a high interest 
rate and therefore may receive a smaller loan when entering a loan contract. Moreover, we also predicted that the impact of ESG incidents on loan terms would be more pronounced in younger firms. This is because soft information usually works for clients that have higher information asymmetry.

Prior studies have proven that a bank's behavior is affected by companies' corporate governance and social responsibility using data from KLD stats, which is quite a rough database that offers ESG scores with lower variety over the years [16]. Therefore, our research contributes to the literature by investigating the relationship between environmental, social, and governance incidents and bank loan contracts. We exploited the unique role of banks as "quasi-insiders" of a firm to explore whether lenders discriminate firms with ESG incidents. We used data from RepRisk, which constructs its database of ESG incidents by screening over 80,000 media, regulatory, and commercial documents in 15 different languages, divided into 30 categories. It is a novel event-based database about ESG issues, and it has been tracking firms' events related to ESG issues from 2007. We used the aggregated measure of ESG provided by this database as a proxy for ESG performance. There are several advantages of this measure. First, this measure is constructed based on public sources, such as media and commercial documents; therefore, these data are updated timely in empirical models. Second, data collected from widely spread public sources are usually more comprehensive and more precise. Finally, the database is daily updated. The results showed that firms with worse ESG performance usually have a higher loan spread and a relatively small amount in terms of loan size. Moreover, a firm's age could weaken the negative impact of their worse ESG performance on loan contract terms. This is consistent with our prediction above.

We also did some additional tests to strengthen our above conclusion. First, we considered the timing of the ESG incidents for each year. The loan contract can be impacted by ESG incidents only when said contract is issued after the month in which the ESG incident occurred during the year. Second, we decomposed the aggregate measure into three parts: environmental, social, and governance. The results showed that the collusion above is mainly driven by environmental issues. Furthermore, we also considered other non-monetary terms in the contracts. We found that firms with more ESG incidents are more likely to be asked for collateral, have relatively short loan durations, and get more covenants in terms of the loan contract. Moreover, there are fewer lenders for loan contracts issued to clients with ESG incidents. Finally, we also conducted several robustness checks, such as control for firm fixed effects, control for KLD scores, control for lender's fixed effects, and control for collateral, loan purpose, and type of loan. Our results remained unchanged under these robustness checks.

Our results contribute to a growing body of literature that examines the economic consequences of ESG incidents and the determinants of loan cost for public firms (e.g., [8,17]). In particular, our study is the first to use data completely related to ESG incidents to identify causality, as well as the first to measure the effects of the intensity and influence of environmental, social, and governance incidents on bank loan pricing and size. More broadly, our results also contribute to public policy discussions on the role banks should play in the transition to a low-carbon and sustainable economy. By documenting the significant impact of ESG incidents on various features of loan contracts, our paper also adds to the literature on the determinants of bank loan contract terms and the literature on the impact of CSR.

The remainder of this paper proceeds as follows. Section 2 reviews the related literature and develops the hypotheses. Section 3 describes the sample and research design adopted by the paper. Section 4 presents the baseline results. Then, we report the results of additional tests in Section 5. Finally, Section 6 concludes our paper. 


\section{Literature Review and Hypothesis Development}

\subsection{Literature Review}

Two streams of literature are related to our research. The first comprises studies that focus on the economic consequences of public firms' ESG performance. The second is the literature that exploits the determinants of bank loan costs and, subsequently, the cost of capital, as well as capital structure. Given the research question in this paper and the extant literature regarding each aspect, we mainly reviewed papers that related to both of these aspects.

Firms' ESG performance has long been studied from the perspective of their financing activities. For example, firms will have higher loan costs and lower credit ratings if they face severer environmental and social concerns. This result is from [5], where the ESG scores were taken from the KLD database. There is also literature that exploits this issue in a more detailed way. For example, firms will have a lower debt ratio if they are exposed to higher climate-related risk [8]; Chang et al. [18] found that a higher environmental risk decreases the possibility of the firm to get a loan, resulting in lower leverage ratio; meanwhile, an improved environmental performance lowers the cost of capital, leading to a higher leverage ratio [19]. Additionally, lower carbon emissions could improve bond performance, exhibited as higher bond yields [20]. Investors also respond positively to the issuance of green bonds, which are bonds that are used to support environmentally friendly projects. Moreover, literature aimed at determining the disclosure of ESG issues also matters. Chava and Roberts [21] focused on the impact of a firm's environmental issues on the cost of debt, and the results showed that firms pay higher loan costs on a bank loan if they are faced with significant economic concerns. However, the data source of [21] came from the KLD database, which comprises quite rough data that measure a firm's economic concerns, leading to difficulty in identifying the causality. As argued by [16], the measure in the KLD database is lower in variety across years. Unlike the data in KLD stats, our event-based data from the RepRisk platform provide a much more timely, detailed, and accurate measure of ESG performance.

Additionally, some papers focus on the relationship between climate change risk, which is an important aspect of ESG and loan costs. For example, the reservation of fossil fuels loses economic value during transition to a low-carbon economy [17]. The results in this paper showed that the loan spread is significantly increased after the Paris Agreement period. Jung et al. [22] found that disclosure of firms' carbon emissions could decrease loan costs. Flammer [23] documented that investors respond positively to climatefriendly projects and issuance announcements, with issuers improving their environmental performance post-issuance. Matsumura et al. [24] and Griffin et al. [25] used voluntary disclosures of greenhouse gas emissions to show market price carbon emissions as a negative component of equity value. Baker et al. [26] studied the market of municipal bonds and found that green municipal bonds are issued at a premium to otherwise similar municipal bonds.

Building on the above literature, our study isolated the effect of ESG incidents from other compounding factors on loan cost and identified the causality of the effects of ESG incidents on loan contracts by using the new event-based ESG database. As a result, we propose new evidence that banks take ESG incidents into consideration when issuing loan contracts to their clients, and that banks play a vital political role in a low-carbon and sustainable economy.

\subsection{Hypothesis Development}

We propose that ESG incidents can affect the pricing and terms of loan contracts via two channels. The first is that ESG incidents can reveal information about the sustainable and environmental development risks faced by firms, as well as the risk management processes in place to mitigate such risks. These risks can significantly affect the level and uncertainty of a firm's future cash flows, which can, in turn, affect said firm's ability to repay its loans, as well as the value of the collateral that could be recovered in the case 
of default. Sharfman and Fernando [19] proposed that the future cash flows of client firms can be affected by expenditures that might have to comply with current and future environmental regulations. Beuer and Hann [5] posited that penalties and liabilities arising from environmental or social negligence impact the credit standing of companies. Moreover, banks might have to face additional liability if environmental regulations subordinate the claims of debt holders [27].

The second is reputational risk. Reputational risk refers to the possibility of being associated with a client firm's environmental or social scandal, and it requires a premium to judge a lending relationship with a firm that the public and the bank's other stakeholders may view as having socially or environmentally questionable behaviors [15]. As public concern about environmental development has increased, public or financial institutions are more likely to practice responsible lending. Lee et al. [28] found that bad news tends to spread quickly; therefore, corporate reputation becomes more important for relevant corporations. This pressure requires banks to disclose the impact of their lending decisions on ESG incidents scores. Considering such reputational risks, banks are more cautious to make loan agreements.

Accordingly, we postulate that lenders price the risk of environmental and social problems and charge higher interest rates and smaller loan sizes to firms with such incidents to compensate for the increased credit and reputational risk.

Hypothesis 1 (H1). Borrowing costs are higher and borrowing sizes are small for companies' clients that have ESG incidents.

Credit risk is the highest risk faced by banks and the most important determinant of loan pricing. The characteristics of released financial information reflect credit risks [29]. Banks usually determine their credibility using disclosures, assurance levels, and thirdparty authentication such as those by auditors [30]. Information asymmetry in a lending relationship indicates that reliable hard information collected about a firm's debt-paying ability leads to soft information about less-dependent banks. Firm age is a particular characteristic of a firm associated with the degree of information asymmetry [31]. Demiroglu and James [32] indicated that larger and older companies are likely to have fewer risks. Chan et al. [33] highlighted that firms of a larger size and an older age have lower information asymmetry because they usually have a larger number of shareholders. Poon and Evans [34] proved that there is a negative relationship between information asymmetry and firm size. They stated that bond rating changes trigger fewer market reactions for smaller firms. Uchida et al. [35] also proved that bank loan costs are higher in smaller and younger entities with a relatively higher degree of information asymmetry. Herein, we predict that banks will pay less attention to the soft information of old firms.

Based on the argument above, we propose our second hypothesis:

Hypothesis 2 (H2). Borrower age weakens the negative relationship between ESG incidents and loan cost and size.

\section{Methodology}

\subsection{Sample and Data}

The data for this research were obtained from various sources: the data of US firms who experienced ESG incidents between 2007 and 2016 were from RepRisk (RepRisk is a global leader and pioneer in data science, specializing in premium ESG and business conduct risk research and quantitative solutions; https://www.reprisk.com (accessed on 10 December 2020)), a database focused on ESG issues. This database collects data about ESG performance (adverse ESG coverage) from more than 80,000 media, regulatory, and commercial documents in 15 different languages. The data are more accurate and comprehensive than those of preview studies. RepRisk collects data following four steps: (1) screening and identification, (2) analysis and curation, (3) quality assurance, and (4) 
quantification. The first step is to identify any computer or project associated with an ESG risk incident. Then, the results of the previous step are delivered to the RepRisk analyst team to further curate the identified risk incidents, including a summary. Before an item is published on the RepRisk platform, it undergoes a quality assurance check and requires approval by a senior RepRisk analyst. The final step is quantification of the risk, which is done through data science.

There are multiple aspects of ESG incidents in the RepRisk database. In this study, we only focused on the RepRisk index (RRI). RRI is a proprietary algorithm that was developed by RepRisk, which dynamically captures and quantifies a company's or project's reputational exposure to ESG and business conduct risks. This measure is an indicator of reputational risk related to ESG issues and the business conduct of a company or project. The RRI ranges from 0 (lowest) to 100 (highest); the higher the value, the higher the risk exposure. The calculation of the RRI is based on two factors: (1) news value, where each news item impacts the RRI to a different extent depending on the influence, severity, and novelty of the news; and (2) news intensity, which refers to the frequency and timing of the information. The RRI emphasizes companies that are newly exposed or have had less exposure in the past; in other words, companies with a lot of past exposure are less sensitive to new exposure (https:/ / www.reprisk.com (accessed on 10 December 2020)). This feature helps with identification, in that new exposure to ESG risk is more likely to be noticed by lenders.

Our sample contained firms covered by RepRisk starting in 2007, as RepRisk began tracking firms' ESG performance from January 2007. Since the RepRisk index data are disclosed monthly, we measured the yearly ESG performance of a firm using two methods, namely, the average RRI and the maximum RRI. The average RRI (Avg RRI) is the mean value of the monthly RRI, while the Max RRI is the maximum value of the monthly RRI.

We obtained firms' financial statement data from the Compustat database, and the details about bank loans from Thomson Reuter's DealScan. Following Chava and Roberts [21] and Schwert [36] (these two papers provide the Gvkey and Facilityid link table), we merged the financial data from Compustat and the loan data from DealScan. Similar to previous studies about bank loans (e.g., [11]), we conducted our analysis at the facility level, that is, we treated each loan contract as one observation. Our final sample comprised 10,562 unique loans for 2001 publicly traded U.S. firms from 2007 to 2016. To merge the RepRisk data (the identifiers in this database are the private ID of RepRisk and ISIN), we obtained the link table of ISIN and GVKEY through Capital IQ. For those ISINs linked with more than one GVKEY, we deleted them manually.

\subsection{Research Design}

To test our above hypotheses, we employed the following regression models:

$$
\text { Loan Spread }_{i t} / \text { Size }_{i t}=\beta_{0}+\beta_{1} R R I_{i t}+\text { Controls }+ \text { Industry }+ \text { year }+\mu_{i t}
$$

where $i$ denotes firms and $t$ represents time. We used Loan Spread and Loan Size to measure the favorableness of bank loan contracts, where Loan Spread is the amount the borrower pays in bps over LIBOR for each dollar drawn down, and Loan Size is the logarithm of the amount of a facility measured using US dollars, as these are the most directly observable outcome variables. In additional tests, we repeated our analysis using alternative measures, such as secured loan duration and the number of covenants, and we obtained similar results. In model (1), which was used to test our first hypothesis, the variable of interest was RRI, which was measured using both the average and maximum values of the monthly RRI published on the RepRisk platform. The higher the value of these two measures, the worse the ESG performance. As discussed in the hypothesis development, the coefficient of this measure should be significantly positive when the dependent variable is Loan Spread and significantly negative when the dependent variable is Loan Size. 
We controlled for a set of client and loan characteristics that may be related to loan contracts. Specifically, we controlled for firm size (Size), measured using the logarithm of total assets; profitability ( $R O A)$, measured using the return on assets; leverage (Leverage), measured using the debt-to-asset ratio; operational risk (Operational Risk), measured using the volatility of the cash flow from operations; asset tangibility (Tangibility), measured using the gross PPE-to-asset ratio; the market-to-book ratio; financial health status (Altman Z). For loan characteristics, we controlled for the loan size (Loan Size), and for the duration of the loan (Loan Maturity), the dependent variable was Loan Spread. We only controlled for the duration of the loan (Loan Maturity) when the dependent variable was Loan Size. To control for the possible time-invariant difference across industries and years, we also added the industry (we used the Fama-French 30 industry classifications) and year fixed effects to our model. Additionally, the standard errors of all of the regressions were clustered at a firm level to mitigate autocorrelation concerns. The definitions of all of the variables are provided in Appendix A.

\section{Main Results}

\subsection{Summary Statistics}

We report the summary statistics for all of the variables used in the main analysis using the mean, median, standard deviation, and 25th and 75th percentiles in Table 1 . The Avg RRI and Max RRI have mean values of 10.461 and 20.396, respectively. The standard deviations and the percentiles of these two variables suggest that the ESG performance has large variations across firms. Moreover, our main dependent variable, Loan Spread, has a mean (median) value of approximately 202 (175) bps with a standard deviation of 126. For the Loan Size, this has a mean (median) size of approximately $\$ 832$ million (\$400 million), with a standard deviation of approximately $\$ 1.219$ billion. Our sample of loans has a mean (median) maturity of approximately 53 (61) months, with a standard deviation of approximately 20 months. In terms of the firm characteristics, the firms in the sample have a mean asset size of $\$ 5.699$ billion, a return on asset of $11.9 \%$, a leverage ratio of $32.9 \%$, an operational risk ratio of 0.044 , an asset tangibility ratio of 0.569 , a market-to-book ratio of 2.980, and an Altman Z score of 2.835 .

Table 1. Summary statistics.

\begin{tabular}{ccccccc}
\hline Variable & $\boldsymbol{N}$ & Mean & SD & Median & P25 & P75 \\
\hline Loan Spread & 10,562 & 202.768 & 126.222 & 175.000 & 125.000 & 250.000 \\
Loan Size & 10,562 & 832.766 & 1219.084 & 400.000 & 175.000 & 1000.000 \\
Ln (Loan Size) & 10,562 & 5.981 & 1.341 & 6.091 & 5.187 & 6.908 \\
Maturity & 10,562 & 53.034 & 19.544 & 61.000 & 39.000 & 61.000 \\
Ln (Maturity) & 10,562 & 3.863 & 0.534 & 4.111 & 3.664 & 4.111 \\
Avg RRI & 10,562 & 10.461 & 12.162 & 6.250 & 0.000 & 19.167 \\
Max RRI & 10,562 & 20.396 & 19.152 & 24.000 & 0.000 & 34.000 \\
Firm Size & 10,562 & 8.648 & 1.639 & 8.579 & 7.519 & 9.739 \\
ROA & 10,562 & 0.119 & 0.072 & 0.111 & 0.078 & 0.154 \\
Leverage & 10,562 & 0.329 & 0.178 & 0.319 & 0.202 & 0.453 \\
Operation Risk & 10,562 & 0.044 & 0.052 & 0.030 & 0.017 & 0.052 \\
Tangibility & 10,562 & 0.569 & 0.420 & 0.504 & 0.204 & 0.884 \\
MB & 10,562 & 2.980 & 3.930 & 1.897 & 1.159 & 3.197 \\
Altman Z & 10,562 & 2.835 & 2.126 & 2.371 & 1.407 & 3.666 \\
\hline
\end{tabular}

\subsection{Results of Multivariate Analysis}

\subsubsection{Results for $\mathrm{H} 1$}

Panel A of Table 2 shows the results of model (1), showing how firms' ESG incidents impact their loan contracts (the loan spread and loan size) when using the average RRI value to measure ESG performance. Column (1) provides the results when the dependent variable was Loan Spread, and Column (2) indicates the result of Loan Size. As predicted, the coefficient of $A v g R R I$ in the first column is positive and significant $(0.420, t$-stat. $=3.68)$, 
implying that a worse ESG performance will bring a firm a higher loan spread when raising a fund through debt. In Column (2), the firms who have experienced ESG incidents receive a lower loan amount in a loan contract, as the coefficient of $A v g R R I$ is significantly negative $(-0.006, t$-stat. $=-4.85)$. Furthermore, the magnitude of the coefficient of Avg RRI is economically meaningful. A one standard deviation increase in $A v g R R I$ is associated with an approximately 5 bps increase in the loan spread. A change of 5 bps represents an increase of approximately $2.5 \%$ relative to a mean loan spread of $202 \mathrm{bps}$. Additionally, a one standard deviation increase in Max RRI is associated with an approximately $\$ 1.08$ million decrease in loan size. A change in $\$ 1.08$ million represents a decrease of approximately $0.25 \%$ relative to the mean value of the loan size.

Regarding the control variables, firms that are large, more profitable, with more tangible assets, and better financial health have a significantly lower loan spread. However, firms with high debt ratios and operational risk often have higher loan spreads. Moreover, large, more profitable firms tend to raise more debt in a loan contract.

Table 2. Environmental, social, and governance (ESG) incidents and bank loans.

\begin{tabular}{|c|c|c|}
\hline Panel A & (1) & (2) \\
\hline & Loan Spread & Ln (Loan Size) \\
\hline$A v g R R I$ & $\begin{array}{c}0.420 * * * \\
(3.68)\end{array}$ & $\begin{array}{c}-0.006^{* * *} \\
(-4.85)\end{array}$ \\
\hline Ln (Loan Size) & $\begin{array}{c}-10.942^{* * *} \\
(-11.96)\end{array}$ & \\
\hline Ln (Maturity) & $\begin{array}{c}14.736^{* * *} \\
(7.46)\end{array}$ & $\begin{array}{c}0.059 * * * \\
(2.79)\end{array}$ \\
\hline Firm Size & $\begin{array}{c}-19.361 \text { *** } \\
(-19.33)\end{array}$ & $\begin{array}{c}0.502 * * * \\
(52.96)\end{array}$ \\
\hline$R O A$ & $\begin{array}{c}-214.813^{* * *} \\
(-11.61)\end{array}$ & $\begin{array}{c}1.073^{* * *} \\
(5.45)\end{array}$ \\
\hline Leverage & $\begin{array}{c}139.735^{* * *} \\
(18.65)\end{array}$ & $\begin{array}{c}0.227^{* * * *} \\
(2.85)\end{array}$ \\
\hline Operation Risk & $\begin{array}{c}238.696^{* * *} \\
(11.74)\end{array}$ & $\begin{array}{l}0.083 \\
(0.38)\end{array}$ \\
\hline Tangibility & $\begin{array}{c}-33.181^{* * *} \\
(-9.85)\end{array}$ & $\begin{array}{c}-0.106^{* * *} \\
(-2.94)\end{array}$ \\
\hline$M B$ & $\begin{array}{l}-0.491 * \\
(-1.67)\end{array}$ & $\begin{array}{c}0.015^{* * *} \\
(4.81)\end{array}$ \\
\hline Altman $z$ & $\begin{array}{c}-10.691^{* * *} \\
(-13.52)\end{array}$ & $\begin{array}{c}0.027^{* * * *} \\
(3.23)\end{array}$ \\
\hline Constant & $\begin{array}{c}317.776^{* * *} \\
(23.51)\end{array}$ & $\begin{array}{c}1.427^{* * *} \\
(9.95)\end{array}$ \\
\hline Industry & Yes & Yes \\
\hline Year & Yes & Yes \\
\hline$F$ & 120.48 & 120.98 \\
\hline Adj. $R$-Squared & 0.352 & 0.348 \\
\hline$N$ & 10,562 & 10,562 \\
\hline
\end{tabular}


Table 2. Cont.

\begin{tabular}{|c|c|c|}
\hline Panel B & (1) & (2) \\
\hline & Loan Spread & Ln (Loan Size) \\
\hline Max RRI & $\begin{array}{c}0.372 * * * \\
(5.42)\end{array}$ & $\begin{array}{c}-0.003 * * * \\
(-4.49)\end{array}$ \\
\hline Ln (Loan Size) & $\begin{array}{c}-10.884^{* * *} \\
(-11.91)\end{array}$ & \\
\hline Ln (Maturity) & $\begin{array}{c}14.832 * * * \\
(7.52)\end{array}$ & $\begin{array}{c}0.060 * * * \\
(2.84)\end{array}$ \\
\hline Firm Size & $\begin{array}{c}-19.851^{* * *} \\
(-20.84)\end{array}$ & $\begin{array}{c}0.496^{* * *} \\
(55.49)\end{array}$ \\
\hline$R O A$ & $\begin{array}{c}-216.014^{* * *} \\
(-11.69)\end{array}$ & $\begin{array}{c}1.090^{* * *} \\
(5.54)\end{array}$ \\
\hline Leverage & $\begin{array}{c}140.433^{* * *} \\
(18.77)\end{array}$ & $\begin{array}{c}0.234^{* * *} \\
(2.93)\end{array}$ \\
\hline Operation Risk & $\begin{array}{c}238.999 * * * \\
(11.77)\end{array}$ & $\begin{array}{l}0.070 \\
(0.32)\end{array}$ \\
\hline Tangibility & $\begin{array}{c}-33.279 * * * \\
(-9.90)\end{array}$ & $\begin{array}{c}-0.109 * * * \\
(-3.03)\end{array}$ \\
\hline$M B$ & $\begin{array}{l}-0.512 * \\
(-1.74)\end{array}$ & $\begin{array}{c}0.015^{* * *} \\
(4.73)\end{array}$ \\
\hline Altman $z$ & $\begin{array}{c}-10.666^{* * *} \\
(-13.51)\end{array}$ & $\begin{array}{c}0.026^{* * *} \\
(3.12)\end{array}$ \\
\hline Constant & $\begin{array}{c}318.352^{* * *} \\
(23.89)\end{array}$ & $\begin{array}{c}1.482 * * * \\
(10.48)\end{array}$ \\
\hline Industry & Yes & Yes \\
\hline Year & Yes & Yes \\
\hline$F$ & 120.99 & 120.87 \\
\hline Adj. $R$-Squared & 0.353 & 0.348 \\
\hline$N$ & 10,562 & 10,562 \\
\hline
\end{tabular}

The $t$-statistics are reported in parentheses. ${ }^{* * *}$ and ${ }^{*}$ indicate statistical significance at the $1 \%$ and $10 \%$ levels, respectively.

Panel B of Table 2 provides the empirical results of model (1) for the test of H1, but the key independent is Max RRI instead, as the firms that have experienced ESG incidents in a year are more likely to draw the attention of others. Similar to the results in the previous table, the results shown are as predicted. The coefficient on our key independent variable is statistically significant and positive $(0.372, t$-stat. $=5.42)$ when the dependent variable was Loan Spread, as shown in Column (1). Additionally, there is a statistically significant and negative coefficient of Max RRI (-0.003, $t$-stat. $=-4.49)$, as shown in Column (2), when the dependent variable was Loan Size. These results support our first hypothesis that firms with worse ESG performance will get less favorable loan contracts, exhibited as a higher loan spread and a lower loan size. Moreover, the results in this table are economically significant. A one standard deviation increase in Max RRI is associated with a $7 \mathrm{bps}$ increase in loan spread. This change means an increase of approximately $3.5 \%$ relative to a mean loan spread of 202 bps. Regarding loan size, a one standard deviation increase in Max RRI is associated with a \$1.06 million decrease in loan size. This represents a decrease of approximately $0.25 \%$ relative to the mean value of the loan size. Additionally, the coefficients on control variables are rationally distributed.

\subsubsection{Results for $\mathrm{H} 2$}

To test our second hypothesis, we did a split sample regression according to the median value of firm age. According to $\mathrm{H} 2$, the absolute value of coefficient on our ESG incidents measure should be larger in the subsample that has a firm age less than the median value of the firm age of the whole sample. We report the results regarding $\mathrm{H} 2$ in Panel A of Table 3, where Columns (1) and (2) are the results of Loan Spread, and Columns (3) 
and (4) are the results of Loan Size. Column (1) is the subsample with a firm age larger than the median age and Column (2) is the subsample with a firm age less than the median age. The results show that the coefficient of $A v g R R I$ is larger in Column (2) $(0.507, t$-stat. $=2.86)$ than in Column (1) $(0.254, t$-stat. $=1.74)$. Moreover, the bootstrap test confirms a significant difference in the coefficient between these two subsamples. This result supports $\mathrm{H} 2$, that the adverse influence of ESG incidents on the loan spread is more pronounced in younger firms. Additionally, there is the same trend for the results of Loan Size. The influence of ESG incidents is more pronounced in the subsample that has a small firm age $(-0.008$, $t$-stat. $=-4.39)$ than in the subsample with a large firm age $(-0.005, t$-stat. $=-2.80)$. The significance of the difference was confirmed by the bootstrap test. In Table 3, we redid the test above using Max RRI. As predicted, the results in Table 3 are quite similar to those in Table 2. Overall, the results above support our hypothesis that ESG incidents serve as a type of soft information that is more important among younger firms when financial institutes are making a loan contract decision.

Table 3. ESG incidents, firm age, and loan contracts.

\begin{tabular}{|c|c|c|c|c|}
\hline \multirow[t]{2}{*}{ Panel A } & \multicolumn{2}{|c|}{ Loan Spread } & \multicolumn{2}{|c|}{ Ln (Loan Size) } \\
\hline & (1) & (2) & (3) & (4) \\
\hline & Age $>$ Median & Age $<$ Median & Age $>$ Median & Age $<$ Median \\
\hline $\operatorname{Avg} R R I$ & $\begin{array}{c}0.254 \text { * } \\
(1.74)\end{array}$ & $\begin{array}{c}0.507^{* * *} \\
(2.86)\end{array}$ & $\begin{array}{c}-0.005^{* * *} \\
(-2.80)\end{array}$ & $\begin{array}{c}-0.008^{* * *} \\
(-4.39)\end{array}$ \\
\hline $\begin{array}{l}\text { Difference } \\
\text { between } \\
\text { coefficients }\end{array}$ & \multicolumn{2}{|c|}{$-0.253 *(0.09)$} & \multicolumn{2}{|c|}{$0.003 *(0.08)$} \\
\hline $\begin{array}{l}\text { Controls } \\
\text { Industry } \\
\text { Year }\end{array}$ & $\begin{array}{l}\text { Yes } \\
\text { Yes } \\
\text { Yes }\end{array}$ & $\begin{array}{l}\text { Yes } \\
\text { Yes } \\
\text { Yes }\end{array}$ & $\begin{array}{l}\text { Yes } \\
\text { Yes } \\
\text { Yes }\end{array}$ & $\begin{array}{l}\text { Yes } \\
\text { Yes } \\
\text { Yes }\end{array}$ \\
\hline $\begin{array}{c}F \\
\text { Adj. } R-S q u a r e d \\
N\end{array}$ & $\begin{array}{l}63.62 \\
0.370 \\
5112\end{array}$ & $\begin{array}{l}54.97 \\
0.322 \\
5450\end{array}$ & $\begin{array}{l}59.52 \\
0.350 \\
5112\end{array}$ & $\begin{array}{l}64.06 \\
0.352 \\
5450\end{array}$ \\
\hline \multirow[t]{2}{*}{ Panel B } & \multicolumn{2}{|c|}{ Loan Spread } & \multicolumn{2}{|c|}{$\operatorname{Ln}($ Loan Size $)$} \\
\hline & Age $>$ Median & Age $<$ Median & Age $>$ Median & Age $<$ Median \\
\hline $\operatorname{Max} R R I$ & $\begin{array}{c}0.241^{* * *} \\
(2.66)\end{array}$ & $\begin{array}{c}0.464^{* * *} \\
(4.56)\end{array}$ & $\begin{array}{c}-0.003^{* * *} \\
(-2.65)\end{array}$ & $\begin{array}{c}-0.004^{* * *} \\
(-3.70)\end{array}$ \\
\hline $\begin{array}{c}\text { Difference } \\
\text { between } \\
\text { coefficients }\end{array}$ & \multicolumn{2}{|c|}{$-0.223^{* *}(0.04)$} & \multicolumn{2}{|c|}{$0.001 * *(0.05)$} \\
\hline $\begin{array}{l}\text { Controls } \\
\text { Industry } \\
\text { Year }\end{array}$ & $\begin{array}{l}\text { Yes } \\
\text { Yes } \\
\text { Yes }\end{array}$ & $\begin{array}{l}\text { Yes } \\
\text { Yes } \\
\text { Yes }\end{array}$ & $\begin{array}{l}\text { Yes } \\
\text { Yes } \\
\text { Yes }\end{array}$ & $\begin{array}{l}\text { Yes } \\
\text { Yes } \\
\text { Yes }\end{array}$ \\
\hline $\begin{array}{c}F \\
\text { Adj. } R \text {-Squared } \\
N\end{array}$ & $\begin{array}{l}63.76 \\
0.371 \\
5112\end{array}$ & $\begin{array}{l}55.36 \\
0.324 \\
5450\end{array}$ & $\begin{array}{l}59.49 \\
0.350 \\
5112\end{array}$ & $\begin{array}{l}63.88 \\
0.352 \\
5450\end{array}$ \\
\hline
\end{tabular}

The $t$-statistics are reported in parentheses. ${ }^{* * *},{ }^{* *}$, and ${ }^{*}$ indicate statistical significance at the $1 \%, 5 \%$, and $10 \%$ levels, respectively.

\section{Additional Tests}

\subsection{Decomposing the ESG Measure}

As known, the measure of ESG incidents in the above section is an aggregate measure of ESG that combines environmental, social, and governance incidents. In this section, we decomposed the above-aggregated measure of ESG performance into three parts: environmental, social, and governance to see their respective effects. In the RepRisk platform, there are percentages for each part of a firm's experienced ESG incidents. Thus, it 
is easy to decompose the combined measure. The results are shown in Table 4. The overall results are consistent with our argument above, that is, the more ESG incidents, the higher the loan cost and the lower the loan size. However, the power of each part is quite different. The absolute value of the coefficients implies that the environmental aspect is the most powerful part of ESG incidents, followed by the social aspect, with the governance aspect coming last. These results imply that environmental issues are much more important and more likely to draw financial institutes' attention. Linking these results to other situations, studies about ESG incidents could focus more on environmental events, being one of the most powerful factors that can draw others' attention and, subsequently, their behavior.

Table 4. Decomposed ESG measures and loan contracts.

\begin{tabular}{|c|c|c|c|c|c|c|}
\hline & (1) & (2) & (3) & (4) & (5) & (6) \\
\hline & $\begin{array}{c}\text { Loan } \\
\text { Spread }\end{array}$ & $\begin{array}{l}\text { Ln }(\text { Loan } \\
\quad \text { Size })\end{array}$ & $\begin{array}{c}\text { Loan } \\
\text { Spread }\end{array}$ & $\begin{array}{l}\text { Ln }(\text { Loan } \\
\quad \text { Size })\end{array}$ & $\begin{array}{c}\text { Loan } \\
\text { Spread }\end{array}$ & $\begin{array}{c}\text { Ln (Loan } \\
\quad \text { Size })\end{array}$ \\
\hline Environmental & $\begin{array}{c}0.789 * * * \\
(3.39)\end{array}$ & $\begin{array}{c}-0.011^{* * *} \\
(-4.51)\end{array}$ & & & & \\
\hline Social & & & $\begin{array}{c}0.445^{* *} \\
(2.39)\end{array}$ & $\begin{array}{c}-0.005^{* *} \\
(-2.48)\end{array}$ & & \\
\hline Governance & & & & & $\begin{array}{l}0.270 \\
(1.41)\end{array}$ & $\begin{array}{c}-0.004^{* *} \\
(-2.11)\end{array}$ \\
\hline Controls & Yes & Yes & Yes & Yes & Yes & Yes \\
\hline Industry & Yes & Yes & Yes & Yes & Yes & Yes \\
\hline Year & Yes & Yes & Yes & Yes & Yes & Yes \\
\hline$F$ & 120.42 & 120.88 & 120.23 & 120.42 & 120.11 & 120.36 \\
\hline Adj. $R$-Squared & 0.352 & 0.348 & 0.351 & 0.347 & 0.351 & 0.347 \\
\hline$N$ & 10,562 & 10,562 & 10,562 & 10,562 & 10,562 & 10,562 \\
\hline
\end{tabular}

The $t$-statistics are reported in parentheses. ${ }^{* * *}$ and ${ }^{* *}$ indicate statistical significance at the $1 \%$ and $5 \%$ levels, respectively.

\subsection{Considering the Timing of the Maximum RRI in A Year}

To further strengthen the causality of our findings, we considered the timing of the maximum RepRisk ESG index in a year. From the previous analysis, we argue that the worst ESG performance in a year is more likely to be noticed by others. Moreover, the DealScan database provides the exact date of each loan contract. Therefore, if this is the case, the loan contract issued before the maximum RRI in a year should not be impacted by bad ESG performance. Only the loan contracts that happened after the maximum RRI (i.e., the worst ESG performance in a year) could be influenced by ESG incidents. Given the argument here, we set a dummy variable equal to one of the facility start dates (i.e., the loan contract issue date) after the maximum RRI month; otherwise, it was zero. We then made this variable interact with Max RRI. According to our conjecture above, the coefficient of this interaction term should be significantly positive when the dependent variable is Loan Spread and significantly negative when the dependent variable is Loan Size. We report the results for this test in Table 5. Column (1) is the test for Loan Spread and Column (2) is for Loan Size. As predicted, the coefficient of the interaction term in Column (1) is significant and positive $(0.318, t$-stat. $=2.04)$, which is consistent with our argument that loan contracts that started after the worst ESG performance in a year are more likely to be impacted, leading to higher loan costs. In Column (2), where the dependent variable was Loan Size, the results are also consistent with our prediction. There is a significant and negative coefficient of the interaction term $(-0.005, t$-stat. $=-3.10)$. The results in this subsection further strengthen our previous results, correcting the timing of the most important event. Clear identification is also very helpful in causal inference. 
Table 5. The timing of the maximum RRI.

\begin{tabular}{ccc}
\hline & $\mathbf{( 1 )}$ & $\mathbf{( 2 )}$ \\
\hline Loan Spread & Ln (Loan Size) \\
\hline Max $R R I^{*}$ After & 0.059 & -0.001 \\
& $(0.41)$ & $(-0.77)$ \\
After & $0.318^{* *}$ & $-0.005^{* * *}$ \\
& $(2.04)$ & $(-3.10)$ \\
Controls & -7.242 & -0.022 \\
Industry & $(-1.52)$ & $(-0.43)$ \\
Year & Yes & Yes \\
$F$ & Yes & Yes \\
Adj. $R$-Squared & Yes & 116.22 \\
$N$ & 114.47 & 0.348 \\
\hline The $t$-statistics are reported in parentheses. ${ }^{* * *}, * *$ & and ${ }^{*}$ indicate statistical significance at the $1 \%, 5 \%$, and $10 \%$ \\
levels, respectively. & &
\end{tabular}

\subsection{Effect of ESG Performance on Other Loan Features}

One of the unique features of bank loans is that they provide multi-dimensional information about a loan contract, so we can explicitly observe the effect of ESG performance on various additional features of loan contracts and their structure. If firms that have experienced ESG incidents indeed have incremental information about the future default risk of firm lending, lenders may incorporate this information into loan contracts by not only adjusting the interest rate, but by modifying other loan contract terms as well, such as requests of collateral, loan duration, and the number of covenants, as well as the syndicate structure and transaction fees, making these terms less favorable for firms with ESG incidents. We tested the impact of ESG incidents on these features in the following subsections.

\subsubsection{Other Loan Contract Terms}

Following previous studies, e.g., [11], we focused on how firms' ESG incidents impact the other three major non-monetary features of the requests of collateral (Secured), loan duration (Loan Maturity), and the number of covenants (\# of Covenants). First, banks may request collateral for a loan contract to manage the possible default risk. We report the results of the impact of ESG incidents on the requests of collateral in Column (1) of Panel A in Table 6. The results show that firms with ESG incidents are more likely to have collateral requested of them when raising funds from the bank, as the coefficient of $A v g R R I$ is positive and significant $(0.001, t$-stat. $=1.94)$. Additionally, banks may shorten the duration of loan contracts to manage the risk. We report the results of how ESG incidents impact loan maturity in Column (2), which shows that ESG incidents result in loans that have relatively short-term maturity $(-0.003, t$-stat. $=-5.82)$. This result supports the conjecture that banks offer less favorable loan terms to firms that exhibit ESG incidents. This finding is also consistent with prior studies arguing that increased client risk reduces a loan's term to maturity $[11,33]$. Moreover, the extant literature contends that lenders use various loan covenants to manage the possible default risk [37]. According to the argument in these studies, we expected lenders to use covenants more frequently for firms with ESG incidents and tested our argument by examining the relationship between RRI and the number of covenants. The results are consistent with our prediction that banks use covenants more frequently for firms with ESG incidents $(0.007, t$-stat. $=2.32)$. This implies that, aside from loan spread and loan size, banks also place more restrictions on other non-monetary terms for firms with ESG incidents. 
Table 6. ESG incidents, other loan contracting terms, and lender structure.

\begin{tabular}{|c|c|c|c|}
\hline Panel A & (1) Secured & $\begin{array}{l}\text { Dependent Variable } \\
\text { (2) Ln (Loan } \\
\text { Maturity) }\end{array}$ & (3) \# of Covenants \\
\hline$A v g R R I$ & $\begin{array}{l}0.001 * \\
(1.94)\end{array}$ & $\begin{array}{l}-0.003^{* * *} \\
(-5.82)\end{array}$ & $\begin{array}{c}0.007^{* *} \\
(2.32)\end{array}$ \\
\hline Control & Yes & Yes & Yes \\
\hline Industry & Yes & Yes & Yes \\
\hline Year & Yes & Yes & Yes \\
\hline$F$ & 83.63 & 33.31 & 17.25 \\
\hline Adj. R-Squared & 0.348 & 0.124 & 0.291 \\
\hline$N$ & 7424 & 10,562 & 1863 \\
\hline Panel B & (1) Ln (\# of lenders) & $\begin{array}{l}\text { Dependent Variable } \\
\text { (2) Ln (Annual Fee) }\end{array}$ & (3) Ln (Upfront Fee) \\
\hline $\operatorname{Avg} R R I$ & $\begin{array}{l}-0.003 * \\
(-1.71)\end{array}$ & $\begin{array}{l}0.006 \\
(1.32) \\
\end{array}$ & $\begin{array}{c}0.005^{* * *} \\
(3.22)\end{array}$ \\
\hline Controls & Yes & Yes & Yes \\
\hline Industry & Yes & Yes & Yes \\
\hline Year & Yes & Yes & Yes \\
\hline$F$ & 16.98 & 8.37 & 32.96 \\
\hline Adj. $R$-Squared & 0.309 & 0.465 & 0.472 \\
\hline$N$ & 1718 & 400 & 1717 \\
\hline
\end{tabular}

The $t$-statistics are reported in parentheses. ${ }^{* * *},{ }^{* *}$, and ${ }^{*}$ indicate statistical significance at the $1 \%, 5 \%$, and $10 \%$ levels, respectively.

\subsubsection{Lending Structure}

We investigated the relationship between ESG incidents and lending structure in this subsection. We treated the impact of ESG incidents on several lenders as an empirical question, as there are different views for this question. For example, Lee and Mullineaux [38] and Graham et al. [11] contended that banks attempt to enhance their efficiency of monitoring by adjusting lending structure; therefore, fewer lenders facilitate decision making and, thus, enhance the efficacy of risk management. According to this argument, there should be fewer lenders for each facility issued to firms with worse ESG performance. However, it is also possible that banks may want to spread the risk by increasing the number of participating banks for each loan contract. As a result, we tested this question empirically. Column (1) of Panel B of Table 6 reports the result of our test for the number of lenders. The significant and negative coefficient of $A v g R R I(-0.003, t$-stat. $=-1.71)$ indicates that the number of lenders decreased for client firms with worse ESG performance. This result further strengthens our conjecture that firms' ESG incidents play a role in bank loan contracting.

\subsubsection{Transaction Fees}

In a syndicated lending arrangement, the lead bank establishes and maintains the relationship with the client and acts as an agent for the syndicate by collecting and processing information about the client and enforcing the terms and covenants of the contract. Before committing to provide funding, the lead bank conducts due diligence, charges an upfront fee at the time of closing a deal, and an annual fee for subsequent service. The sizes of the upfront fee and the annual fee are usually correlated with the complexity and riskiness of a loan. We argue that banks charge more for clients with worse ESG performance. Columns (2) and (3) of Table 6 present the results of our tests for this argument, showing that worse ESG performance could significantly increase the upfront fee $(0.005, t$-stat. $=3.22)$, but has an insignificant influence on the annual fee. However, this insignificant result may be due to the small sample size. 


\subsection{Robustness Tests}

We also did several robustness tests to strengthen the above results. First, we also took bankers' awareness of ESG incidents into consideration. As the awareness of lenders about ESG incidents increases and becomes stronger and stronger, we controlled for the lender * year fixed effects to solve the problem. As shown in Table 7, the results remained unchanged even when we controlled for these fixed effects.

Table 7. Robustness tests: control for lender * year fixed effects.

\begin{tabular}{|c|c|c|c|c|}
\hline & (1) & (2) & (3) & (4) \\
\hline & Loan Spread & Ln (Loan Size) & Loan Spread & Ln (Loan Size) \\
\hline $\operatorname{Avg} R R I$ & $\begin{array}{l}0.568 * * \\
(2.58)\end{array}$ & $\begin{array}{l}-0.003 * \\
(-1.81)\end{array}$ & & \\
\hline $\operatorname{Max} R R I$ & & & $\begin{array}{c}0.553 * * \\
(2.44)\end{array}$ & $\begin{array}{l}-0.001 * \\
(-1.77)\end{array}$ \\
\hline Ln (Loan Size) & $\begin{array}{c}-9.477^{* * *} \\
(-7.00)\end{array}$ & & $\begin{array}{c}-9.459 * * * \\
(-6.99)\end{array}$ & \\
\hline Ln (Maturity) & $\begin{array}{c}7.953 * * * \\
(2.76)\end{array}$ & $\begin{array}{c}0.091^{* * *} \\
(3.03)\end{array}$ & $\begin{array}{c}7.926^{* * *} \\
(2.76)\end{array}$ & $\begin{array}{c}0.092^{* * *} \\
(3.09)\end{array}$ \\
\hline Firm Size & $\begin{array}{c}-21.668^{* * *} \\
(-14.04)\end{array}$ & $\begin{array}{c}0.539^{* * * *} \\
(38.17)\end{array}$ & $\begin{array}{c}-22.386^{* * *} \\
(-15.43)\end{array}$ & $\begin{array}{c}0.533 \\
(40.66)\end{array}$ \\
\hline$R O A$ & $\begin{array}{c}-291.943^{* * *} \\
(-10.03)\end{array}$ & $\begin{array}{c}1.063^{* * *} \\
(3.52)\end{array}$ & $\begin{array}{c}-293.692^{* * *} \\
(-10.10)\end{array}$ & $\begin{array}{c}1.074^{* * *} \\
(3.55)\end{array}$ \\
\hline Leverage & $\begin{array}{c}142.027^{* * *} \\
(13.13)\end{array}$ & $\begin{array}{c}0.258^{* *} \\
(2.30)\end{array}$ & $\begin{array}{c}143.728^{* * *} \\
(13.32)\end{array}$ & $\begin{array}{c}0.264^{* *} \\
(2.35)\end{array}$ \\
\hline Operation Risk & $\begin{array}{c}249.964^{* * *} \\
(9.89)\end{array}$ & $\begin{array}{l}0.166 \\
(0.63)\end{array}$ & $\begin{array}{c}248.637^{* * * *} \\
(9.85)\end{array}$ & $\begin{array}{l}0.162 \\
(0.62)\end{array}$ \\
\hline Tangibility & $\begin{array}{c}-23.104^{* * *} \\
(-4.84)\end{array}$ & $\begin{array}{c}-0.149^{* * *} \\
(-3.00)\end{array}$ & $\begin{array}{c}-23.774^{* * *} \\
(-4.99)\end{array}$ & $\begin{array}{c}-0.151^{* * *} \\
(-3.04)\end{array}$ \\
\hline$M B$ & $\begin{array}{l}0.247 \\
(0.85)\end{array}$ & $\begin{array}{c}0.012 * * * \\
(3.91)\end{array}$ & $\begin{array}{l}0.222 \\
(0.76)\end{array}$ & $\begin{array}{c}0.012 * * * \\
(3.86)\end{array}$ \\
\hline Altman $z$ & $\begin{array}{c}-11.922 * * * \\
(-10.42)\end{array}$ & $\begin{array}{c}0.050 * * * \\
(4.24)\end{array}$ & $\begin{array}{c}-11.859 * * * \\
(-10.40)\end{array}$ & $\begin{array}{c}0.049^{* * *} \\
(4.17)\end{array}$ \\
\hline Constant & $\begin{array}{l}431.399 * * * \\
(23.90)\end{array}$ & $\begin{array}{c}0.725^{* * *} \\
(3.87)\end{array}$ & $\begin{array}{l}431.236^{* * *} \\
(24.45)\end{array}$ & $\begin{array}{l}0.772^{* * *} \\
(4.21)\end{array}$ \\
\hline Fixed effects & $\begin{array}{c}\text { Industry, lender } \\
\text { * year }\end{array}$ & $\begin{array}{c}\text { Industry, lender } \\
\text { * year }\end{array}$ & $\begin{array}{l}\text { Industry, lender } \\
\text { * year }\end{array}$ & $\begin{array}{c}\text { Industry, lender } \\
\text { * year }\end{array}$ \\
\hline pe & 185.68 & 280.55 & 187.97 & 280.31 \\
\hline Adj. R-Squared & 0.342 & 0.387 & 0.345 & 0.387 \\
\hline$N$ & 5271 & 5271 & 5271 & 5271 \\
\hline
\end{tabular}

The $t$-statistics are reported in parentheses. ${ }^{* * *},{ }^{* *}$, and ${ }^{*}$ indicate statistical significance at the $1 \%, 5 \%$, and $10 \%$ levels, respectively.

Some may argue that our results are driven by firms' CSR, as ESG performance is somehow related the CSR. To mitigate the impact of this compound factor, we further controlled for firms' CSR performance by adding the KLD score into our main regression. However, the same results still remained.

Second, to rule out the possibility our results being by other loan explanatory variables that significantly affect loan spread, we further controlled collateral, loan purpose, and type of loan in Table 8. However, the results remained unchanged. 
Table 8. Robustness tests: control for collateral, loan purpose, and type of loan.

\begin{tabular}{|c|c|c|}
\hline & (1) & (2) \\
\hline & Loan Spread & Loan Spread \\
\hline $\operatorname{Avg} R R I$ & $\begin{array}{c}0.171^{* *} \\
(2.23)\end{array}$ & \\
\hline $\operatorname{Max} R R I$ & & $\begin{array}{l}0.244^{* * *} \\
(2.75)\end{array}$ \\
\hline Secured & $\begin{array}{c}17.121^{* * *} \\
(3.85)\end{array}$ & $\begin{array}{c}16.900^{* * * *} \\
(3.80)\end{array}$ \\
\hline Ln (Loan Size) & $\begin{array}{l}-3.185^{* *} \\
(-2.20)\end{array}$ & $\begin{array}{c}-3.234^{* *} \\
(-2.23)\end{array}$ \\
\hline Ln (Maturity) & $\begin{array}{c}-7.146^{* *} \\
(-2.53)\end{array}$ & $\begin{array}{c}-7.189 * * \\
(-2.55)\end{array}$ \\
\hline Firm Size & $\begin{array}{l}-8.838 \\
(-1.46)\end{array}$ & $\begin{array}{c}-10.388 * \\
(-1.71)\end{array}$ \\
\hline$R O A$ & $\begin{array}{c}-207.649^{* * *} \\
(-4.14)\end{array}$ & $\begin{array}{c}-211.333^{* * *} \\
(-4.21)\end{array}$ \\
\hline Leverage & $\begin{array}{c}147.042 * * * * \\
(5.39)\end{array}$ & $\begin{array}{c}144.849^{* * *} \\
(5.31)\end{array}$ \\
\hline Operation Risk & $\begin{array}{l}5.908 \\
(0.13)\end{array}$ & $\begin{array}{l}8.368 \\
(0.18)\end{array}$ \\
\hline Tangibility & $\begin{array}{c}-49.659 * * * \\
(-2.92)\end{array}$ & $\begin{array}{c}-48.846^{* * *} \\
(-2.88)\end{array}$ \\
\hline$M B$ & $\begin{array}{l}-0.084 \\
(-0.17)\end{array}$ & $\begin{array}{l}-0.094 \\
(-0.19)\end{array}$ \\
\hline Altman $z$ & $\begin{array}{l}-2.593 \\
(-1.00)\end{array}$ & $\begin{array}{l}-2.694 \\
(-1.04)\end{array}$ \\
\hline Constant & $\begin{array}{l}212.250 * * * \\
\quad(3.43)\end{array}$ & $\begin{array}{l}227.787^{* * *} \\
\quad(3.68)\end{array}$ \\
\hline Fixed Effects & $\begin{array}{l}\text { Industry, year, loan type, loan } \\
\text { purpose }\end{array}$ & $\begin{array}{c}\text { Industry, year, loan type, loan } \\
\text { purpose }\end{array}$ \\
\hline$F$ & 14.99 & 15.13 \\
\hline Adj. R-Squared & 0.616 & 0.616 \\
\hline$N$ & 5271 & 5271 \\
\hline
\end{tabular}

The $t$-statistics are reported in parentheses. ${ }^{* * *}$ and ${ }^{* *}$ indicate statistical significance at the $1 \%$ and $5 \%$ levels, respectively.

Lastly, as shown in Table 9, we corrected for the probability of getting a loan. Firms with ESG incidents may find it difficult to obtain loans or to raise additional funds. This can have led to potential endogeneity in sample selection when we examined the impact of ESG incidents on loan spread. In particular, we could have been examining firms that were able to borrow funds (and thus for whom loan spread information is available) despite said firms experiencing ESG incidents. Although we found a statistically significant negative impact on loan spread even with this potential selection bias, we nonetheless utilized Heckman's (1979) two-stage correction for robustness in order to address selection issues. 
Table 9. Robustness tests: alternative explanation.

\begin{tabular}{|c|c|c|c|c|}
\hline & (1) & (2) & (3) & (4) \\
\hline & First Stage & Second Stage & First Stage & Second Stage \\
\hline $\operatorname{Avg} R R I$ & $\begin{array}{l}-0.139 * * \\
(-2.37)\end{array}$ & $\begin{array}{c}0.565^{* * *} \\
(3.35)\end{array}$ & & \\
\hline Max RRI & & & $\begin{array}{l}-0.124^{* *} \\
(-2.12)\end{array}$ & $\begin{array}{c}0.598^{* * *} \\
(5.64)\end{array}$ \\
\hline Ln (Loan Size) & & $\begin{array}{c}-11.248^{* * *} \\
(-7.91)\end{array}$ & & $\begin{array}{c}-11.122 * * * \\
(-7.83)\end{array}$ \\
\hline Ln (Maturity) & & $\begin{array}{c}6.622 * * \\
(2.32)\end{array}$ & & $\begin{array}{c}6.693^{* *} \\
(2.35)\end{array}$ \\
\hline Firm Size & $\begin{array}{c}0.272 * * * \\
(61.12)\end{array}$ & $\begin{array}{c}-22.696^{* * *} \\
(-12.99)\end{array}$ & $\begin{array}{c}0.231 * * * \\
(41.74)\end{array}$ & $\begin{array}{c}-23.868^{* * *} \\
(-14.41)\end{array}$ \\
\hline$R O A$ & $\begin{array}{c}0.453 * * * \\
(21.21)\end{array}$ & $\begin{array}{c}-301.200 * * * \\
(-9.85)\end{array}$ & $\begin{array}{c}0.175^{* * * *} \\
(11.37)\end{array}$ & $\begin{array}{c}-302.921^{* * *} \\
(-9.93)\end{array}$ \\
\hline Leverage & $\begin{array}{c}0.658^{* * * *} \\
(21.48)\end{array}$ & $\begin{array}{c}159.380 * * * \\
(12.22)\end{array}$ & $\begin{array}{c}0.930 * * * \\
(16.27)\end{array}$ & $\begin{array}{c}161.776^{* * * *} \\
(12.42)\end{array}$ \\
\hline Operation Risk & $\begin{array}{l}-0.014 \\
(-1.23)\end{array}$ & $\begin{array}{c}218.803^{* * * *} \\
(8.51)\end{array}$ & $\begin{array}{l}-0.025 \\
(-0.93)\end{array}$ & $\begin{array}{c}216.188^{* * * *} \\
(8.43)\end{array}$ \\
\hline Tangibility & $\begin{array}{c}0.032 * * * \\
(3.17)\end{array}$ & $\begin{array}{c}-45.019 * * * \\
(-7.35)\end{array}$ & $\begin{array}{c}0.027 * * * \\
(3.61)\end{array}$ & $\begin{aligned}- & 45.535 * * * \\
& (-7.46)\end{aligned}$ \\
\hline$M B$ & $\begin{array}{l}-0.000 \\
(-0.32)\end{array}$ & $\begin{array}{l}-0.230 \\
(-0.74)\end{array}$ & $\begin{array}{l}-0.000 \\
(-0.15)\end{array}$ & $\begin{array}{l}-0.241 \\
(-0.78)\end{array}$ \\
\hline Altman z & $\begin{array}{l}0.000 \\
(0.89)\end{array}$ & $\begin{array}{c}-9.016^{* * * *} \\
(-7.37)\end{array}$ & $\begin{array}{l}0.000 \\
(0.68)\end{array}$ & $\begin{array}{c}-8.985^{* * *} \\
(-7.36)\end{array}$ \\
\hline lambda & & $\begin{array}{c}8.139^{*} \\
(1.72)\end{array}$ & & $\begin{array}{l}-5.480 \\
(-1.16)\end{array}$ \\
\hline Constant & $\begin{array}{c}-3.531 * * * \\
(-7.03)\end{array}$ & $\begin{array}{c}398.887^{* * * *} \\
(14.98) \\
\end{array}$ & $\begin{array}{c}-7.217^{* *} \\
(-2.17)\end{array}$ & $\begin{array}{c}413.329^{* * * *} \\
(15.80)\end{array}$ \\
\hline Fixed Effects & Industry, year & Industry, year & Industry, year & Industry, year \\
\hline Chi-Squared/F & 3353.87 & 81.85 & 2568.89 & 83.10 \\
\hline$R$-Squared & 0.165 & 0.378 & 0.281 & 0.380 \\
\hline$N$ & 8295 & 5271 & 8295 & 5271 \\
\hline
\end{tabular}

The $t$-statistics are reported in parentheses. ${ }^{* * *},{ }^{* *}$, and ${ }^{*}$ indicate statistical significance at the $1 \%, 5 \%$, and $10 \%$ levels, respectively.

\section{Conclusions}

Using a novel database that focused on firms' ESG incidents, we investigated how firms' ESG incidents influence their bank loan contracts. The results showed that banks offer less favorable loan contract terms to client firms with ESG incidents, manifested as a higher interest rate and a lower loan size, which means that banks take ESG incidents into account when making loan contract decisions. Cross-sectional analysis highlighted that the results above are more pronounced in younger firms, which is consistent with our argument that ESG incidents comprise a type of soft information that works in situations that characterize higher information asymmetry. We also conducted some additional tests and found that the ESG incidents also impact the non-monetary terms in loan contracts. The results showed that ESG incidents also increase the possibility of being asked for collateral, shorten the duration of a loan contract, and increase the frequency of using covenants. As for the lending structure, as well as the transaction fees, it is also less favorable for those firms with ESG incidents. When we decomposed the aggregate measure of ESG performance into environmental, social, and governance incidents to isolate the single effects of each dimension, the results showed that environmental issues are the most powerful factor impacting a bank's loan decision. To further strengthen our results, we also considered the timing of a firm's ESG incidents in a year. The theory is that, if this is the case, then the ESG incidents should only impact the loan contracts issued after the worst. The results also support our prediction. Finally, robustness checks controlling for 
the KLD score and a firm's fixed and related loan variables did not affect our results. We also applied Heckman correction for potential selection bias.

Our results contribute to the growing literature examining the impact of ESG incidents on bank loans for companies (e.g., [8,17]). In particular, our study is the first to use ESG to identify causality, as well as the first to measure the effects of the timing and influence of environmental, social, and governance incidents on bank loan pricing and size. We employed an event-based measure of climate risk using data compiled by RepRisk. Unlike the adoption of emissions and environmental standards reported by firms, our event-based measure of ESG incidents allowed us to explore variations in the timing of specific incidents in order to infer causality and to perform more detailed analysis based on the intensity and influence of the incidents.

We provide systematic evidence that banks incorporate ESG considerations into their lending agreements with corporate clients. By documenting the significant impact of ESG incidents on various features of loan contracts, our paper also adds to the literature on the determinants of bank loan contract terms and the literature on the impact of CSR. Our results also contribute to public policy discussions on the role banks should play in the transition to a low-carbon and sustainable economy. The impact of ESG incidents on capital market and public firms should be researched in more depth in the future.

Author Contributions: Conceptualization, R.H. and X.C.; methodology, R.H.; software, C.C.; validation, C.C., J.Z. and L.C.; formal analysis, R.H.; investigation, X.C.; resources, L.C.; data curation, C.C.; writing—original draft preparation, R.H.; writing—review and editing, L.C.; visualization, L.C. and J.Z.; supervision, J.Z.; project administration, X.C.; funding acquisition, L.C. and X.C. All authors have read and agreed to the published version of the manuscript.

Funding: This study was funded by Beijing Municipal Natural Science Foundation (grant number 9192018).

Informed Consent Statement: Not applicable.

Data Availability Statement: Data are available on request.

Conflicts of Interest: The authors declare no conflict of interest.

\section{Appendix A}

Table A1. Variable definition.

\begin{tabular}{|c|c|}
\hline Variable Name & Definition and Construction \\
\hline \multicolumn{2}{|l|}{ Rep Risk Index } \\
\hline $\operatorname{Avg}(R R$ index $)$ & Mean value of rep risk index in a year (source: RepRisk) \\
\hline $\operatorname{Max}(R R$ index $)$ & The maximum value of rep risk index in a year (source: RepRisk) \\
\hline \multicolumn{2}{|l|}{ Bank Loan Variables } \\
\hline Loan Spread & $\begin{array}{l}\text { The amount the borrower pays in bps over LIBOR for each dollar drawn down } \\
\text { (source: DealScan) }\end{array}$ \\
\hline Loan Size & The loan amount of the facility in million USD (source: DealScan) \\
\hline Ln (Loan Size) & $\begin{array}{c}\text { Natural logarithm of the loan amount of the facility in million USD (source: } \\
\text { DealScan) }\end{array}$ \\
\hline Loan Maturity & The number of months to maturity (source: DealScan) \\
\hline Ln (Loan Maturity) & Natural logarithm of the number of months to maturity (source: DealScan) \\
\hline Secured & $\begin{array}{c}\text { A dummy variable that equals } 1 \text { if the loan facility is secured by collateral and } 0 \\
\text { otherwise (source: DealScan) }\end{array}$ \\
\hline \# of Covenants & $\begin{array}{l}\text { The total number of covenants for a loan contract, following Graham et al. (2008) } \\
\text { (source: DealScan) }\end{array}$ \\
\hline \# of lenders & The total number of lenders of a single loan (source: DealScan) \\
\hline Upfront Fee & $\begin{array}{l}\text { A fee paid by the borrower upon closing a loan (measured in basis points) (source: } \\
\text { DealScan) }\end{array}$ \\
\hline Annual Fee & $\begin{array}{l}\text { Also called facility fee, which is the annual charge against the entire loan } \\
\text { commitment amount, whether used or unused (measured in basis points) (source: } \\
\text { DealScan) }\end{array}$ \\
\hline
\end{tabular}


Table A1. Cont.

\begin{tabular}{|c|c|}
\hline Variable Name & Definition and Construction \\
\hline \multicolumn{2}{|l|}{ Firm-Level Variables } \\
\hline Firm Size & Natural logarithm of total assets in million USD (source: Compustat) \\
\hline$R O A$ & EBITDA scaled by total assets (source: Compustat) \\
\hline Leverage & Current debt and long-term debt scaled by total assets (source: Compustat) \\
\hline Operational Risk & $\begin{array}{l}\text { The standard deviation of yearly cash flows from operations divided by total } \\
\text { assets over the past five fiscal years (source: Compustat) }\end{array}$ \\
\hline Tangibility & Gross PPE scaled by total assets (source: Compustat) \\
\hline Altman Z & $\begin{array}{c}\text { Modified Altman }(1968) \mathrm{Z} \text {-score }=(1.2 \times \text { working capital }+1.4 \times \text { retained } \\
\text { earnings }+3.3 \times \text { income before extraordinary items }+0.999 \times \text { sales }) / \text { total assets } \\
\text { (source: Compustat) }\end{array}$ \\
\hline$M B$ & Market-to-book ratio (source: Compustat) \\
\hline Firm Age & Number of years from the year that the firm was established (source: Compustat) \\
\hline
\end{tabular}

\section{References}

1. International Partnership for Energy Efficiency Cooperation. The Group of Twenty Finance Ministers and Central Bank Governors, Report on the G20 Energy Efficiency Action Plan Voluntary Collaboration on Energy Efficiency; International Partnership for Energy Efficiency Cooperation: Paris, France, 2017.

2. Escrig-Olmedo, E.; Rivera-Lirio, J.M.; Munoz-Torres, M.J.; Fernandez-Izquierdo, M.A. Integrating multiple ESG investors' preferences into sustainable investment: A fuzzy multicriteria methodological approach. J. Clean. Prod. 2017, 162, 1334-1345. [CrossRef]

3. Tarmuji, I.; Maelah, R.; Tarmuji, N.H. The impact of environmental, social and governance practices (ESG) on economic permance: Evidence from ESG score. Int. J. Trade Econ. Financ. 2016, 7, 67. [CrossRef]

4. Sahut, J.M.; Pasquini-Descomps, H. ESG impact on market performance of firms: International Evidence. Manag. Int. Int. Manag. Gestiòn Int. 2016, 19, 40-63.

5. Bauer, R.; Hann, D. Corporate Environmental Management and Credit Risk. Available online: https:/ / ssrn.com/abstract=1660470 (accessed on 23 December 2010).

6. Barnett, M.; Brock, W.; Hansen, L.P. Pricing uncertainty induced by climate change. Rev. Financ. Stud. 2020, 33, 1024-1066. [CrossRef]

7. Hong, H.; Karolyi, G.A.; Scheinkman, J.A. Climate finance. Rev. Financ. Stud. 2020, 33, 1011-1123. [CrossRef]

8. Ginglinger, E.; Moreau, Q. Climate Risk and Capital Structure; Working Paper; Université Paris-Dauphine: Paris, France, 2019.

9. Allman, K.A. Capital Structure and Balance Sheet; John Wiley \& Sons, Ltd.: Chichester, UK, 2015.

10. Bank of England. Enhancing Banks' and Insurers' Approaches to Managing the Financial Risks from Climate Change; Consultation paper 23/18, Prudential Regulation Authority; Bank of England: London, UK, 2018.

11. Graham, J.R.; Li, S.; Qiu, J. Corporate Misreporting and Bank Loan Contracting. J. Financ. Econ. 2008, 89, 44-61. [CrossRef]

12. Goss, A.; Roberts, G.S. The impact of corporate social responsibility on the cost of bank loans. J. Bank. Financ. 2011, 35, 1794-1810. [CrossRef]

13. Barnea, A.; Rubin, A. Corporate Social Responsibility as a Conflict between Shareholders. J. Bus. Ethn. 2010, 97, 71-86. [CrossRef]

14. Ge, W.; Liu, M. Corporate social responsibility and the cost of corporate bonds. J. Account. Public Policy 2015, 34, 597-624. [CrossRef]

15. Simnett, R.; Nugent, M.; Huggins, A. Developing an international assurance standard on greenhouse gas statements. Account. Horiz. 2009, 23, 347-363. [CrossRef]

16. Dhaliwal, D.; Li, O.; Tsang, A.; Yang, Y. Voluntary nonfinancial disclosure and the cost of equity capital: The initiation of corporate social responsibility reporting. Account. Rev. 2011, 86, 59-100. [CrossRef]

17. Delis, M.; de Greiff, K.; Ongena, S. Being Stranded with Fossil Fuel Reserves? Climate Policy Risk and the Pricing of Bank Loans; Working Paper; Montpellier Business School: Montpellier, France, 2019.

18. Chang, X.; Fu, K.; Li, T.; Tam, L.; Wong, G. Corporate Environmental Liabilities and Capital Structure. Available online: https: / / ssrn.com/abstract=3200991 (accessed on 22 June 2018).

19. Sharfman, M.; Fernando, C. Environmental risk management and the cost of capital. Strategy Manag. J. 2008, 29, 569-592. [CrossRef]

20. Chen, L.H.; Silva Gao, L. The pricing of climate risk. J. Financ. Econ. Pract. 2012, 12, 115-131. [CrossRef]

21. Chava, S.; Roberts, M. How does financing impact investment? The role of debt covenants. J. Financ. 2014, 63, $2085-2121$. [CrossRef]

22. Jung, J.; Herbohn, K.; Clarkson, P. Carbon risk, carbon risk awareness and the cost of debt financing. J. Bus. Eth. 2016, 150, 1151-1171. [CrossRef]

23. Flammer, C. Corporate green bonds. J. Franc. Econ. Publ. 2020. ahead of print.

24. Matsumura, E.; Prakash, R.; Vera-Muñoz, S. Firm-value effects of carbon emissions and carbon disclosures. Account. Rev. 2014, 89, 695-724. [CrossRef] 
25. Griffin, P.; Lont, D.; Sun, E. The relevance to investors of greenhouse gas emission disclosures. Contemp. Account. Res. 2017, 34, 1265-1297. [CrossRef]

26. Baker, M.; Bergstresser, D.; Serafeim, G.; Wurgler, J. Financing the Response to Climate Change: The Pricing and Ownership of US Green Bonds; National Bureau of Economic Research: Cambridge, MA, USA, 2018.

27. Kroszner, R.; Strahan, P. Bankers on boards: Monitoring, conflicts of interest, and lender liability. J. Financ. Econ. 2001, 62, 415-452. [CrossRef]

28. Lee, L.; Hutton, A.; Shu, S. The role of social media in the capital market: Evidence from consumer product recalls. J. Account. Res. 2015, 53, 367-404. [CrossRef]

29. Freixas, X.; Rochet, J.C. Microeconomics of Banking (Vol. 2); MIT Press: Cambridge, MA, USA, 1997; Volume 17, p. 2014.

30. Lo, A.K. Accounting Credibility and Liquidity Constraints: Evidence from Reactions of Small Banks to Monetary Tightening. Account. Rev. 2015, 90, 1079-1113. [CrossRef]

31. Chen, C.; Hepfer, B.F.; Quinn, P.J.; Wilson, R.J. The Effect of Tax-Motivated Income Shifting on Information Asymmetry. Rev. Account. Stud. 2018, 23, 958-1004. [CrossRef]

32. Demiroglu, C.; James, C.M. The Information Content of Bank Loan Covenants. Rev. Financ. Stud. 2010, 23, 3700-3737. [CrossRef]

33. Chan, L.H.; Chen, K.C.W.; Chen, T.Y. The effects of firm-initiated clawback provisions on bank loan contracting. J. Financ. Econ. 2013, 110, 659-679. [CrossRef]

34. Poon, W.P.H.; Evans, D.A. Regulation fair disclosure's effect on the information content of bond rating changes. Eur. Financ. Manag. 2013, 19, 775-800. [CrossRef]

35. Uchida, H.; Udell, G.F.; Yamori, N. Loan Officers and Relationship Lending to SMEs. J. Financ. Intermediation 2012, $21,97-122$. [CrossRef]

36. Schwert, M. Bank capital and lending relationships. J. Financ. 2018, 73, 787-830. [CrossRef]

37. Kim, J.; Song, B.Y.; Zhang, L. Internal Control Weakness and Bank Loan Contracting: Evidence from SOX Section 404 Disclosures. Account. Rev. 2011, 86, 1157-1188. [CrossRef]

38. Lee, S.W.; Mullineaux, D.J. Monitoring, Financial Distress, and the Structure of Commercial Lending Syndicates. Financ. Manag. 2014, 33, 107-130. 